\title{
EFFECT OF OLANZAPINE ON INVASION AND METASTASIS OF LUNG CANCER CELLS AND THE NURSING ROLE OF PATIENTS AFTER CHEMOTHERAPY
}

\author{
LIU YANG ${ }^{1}$, XUE YU $^{2}$, YING LIN ${ }^{3}$, NA YANG $^{4}$, DAN LU $^{1}$, SHULI ZHANG ${ }^{1}$, PING DU $^{1}$, \\ XIAOHONG LIU ${ }^{1}$, YING SU ${ }^{1}$, HE ZHANG ${ }^{1}$, GUITING LIU $^{3 *}$ \\ ${ }^{1}$ Central Sterile Supply Department, Affiliated HongQi Hospital of MuDanJiang Medical University, Mudanjiang City \\ 157011, Heilongjiang Province, China \\ ${ }^{2}$ Department of Pharmacy, Affiliated Hongqi Hospital of Mudanjiang Medical University, Mudanjiang City 157011, \\ Heilongjiang Province, China \\ ${ }^{3}$ Department of Thoracic Surgery, Affiliated Hongqi Hospital of Mudanjiang Medical University, Mudanjiang City 157011, \\ Heilongjiang Province, China \\ ${ }^{4}$ Endocrine Department, Affiliated Hongqi Hospital of Mudanjiang Medical University, Mudanjiang City 157011, \\ Heilongjiang Province, China
}

*corresponding author: liuguiting_mjmu@163.com

Manuscript received: April 2018

\begin{abstract}
Chemotherapy-induced nausea and vomiting (CINV), is one of the most common adverse reactions to chemotherapy and the use of preventive medication can influence the success of the therapy. The aim of this study was to assess in vitro and in vivo the effect of olanzapine on the invasion and metastasis of lung cancer cells and the prevention of nausea and vomiting after chemotherapy. The invasion and metastasis of lung squamous carcinoma cells was evaluated in vitro on A549 cells and in vivo on a nude mice non-obese diabetic (NOD)/severe combined immunodeficiency (SCID) lung metastasis model. Also thirty eight lung cancer patients who received chemotherapy were included in the study. The preventive effect of olanzapine on chemotherapy-induced nausea and vomiting was analysed. In vitro experiments showed that olanzapine decreases the cell number and rate of migration and invasion of A549 cells compared to control groups. In vivo olanzapine decreased the metastasis diameter in olanzapine group compared with the control group. The use of olanzapine for preventing chemotherapy-induced nausea and vomiting in lung cancer patients has the benefit of also inhibiting the invasion and metastasis of lung cancer cells.
\end{abstract}

\section{Rezumat}

Greața și vărsăturile induse de chimioterapie (CINV) sunt printre cele mai frecvente reacții adverse care apar în timpul chimioterapiei, iar administrarea medicației preventive poate influența succesul acesteia. Scopul prezentului studiu a fost de a evalua in vitro și in vivo efectul olanzapinei asupra invaziei și riscului de metastazare a cancerului pulmonar precum și a efectului de prevenire a greții și vomei după tratamentul cu chimioterapice. Efectul olanzapinei asupra invaziei și metastazării celulelor de carcinom squamos pulmonar a fost evaluat in vitro pe celulele A549 și in vivo pe modelul metastatic de cancer pulmonar pe şoareci diabetic non-obezi (NOD)/cu imunodeficiență severă combinată (SCID). De asemenea am efectuat un studiu clinic în care am inclus treizeci și opt de pacienți cu cancer pulmonar care au primit chimioterapie. Am evaluat efectul preventiv al olanzapinei asupra greții și vărsăturilor. Experimentele in vitro a arătat că olanzapina scade numărul de celule şi rata de migrare și invazivitate a celulelor A549 comparativ cu lotul de control, iar cele in vivo au arătat că olanzapina scade diametrul metastazelor. Utilizarea olanzapinei pentru prevenirea greței și vărsăturilor induse de chimioterapie la pacienții cu cancer pulmonar prezintă beneficiul de a inhiba de asemenea invazia și metastazarea celulelor canceroase.

Keywords: olanzapine, lung squamous carcinoma cells, postoperative care, cell transfer

\section{Introduction}

After cardiovascular and cerebrovascular diseases, cancer is the third pathology with high morbidity and mortality that affects the human health worldwide [1, 2]. The classic chemotherapy treatment has a wide variety of side effects, chemotherapy-induced nausea and vomiting (CINV) being one of the most common adverse reactions with serious implications on the life quality of these patients $[3,5]$. New treatments with less side effects, such as plant derived molecules, have been tried and showed promising results, but the studies are still at an early stage [4-6]. The control of CINV during chemotherapy treatment is extremely important for improving life quality of these patients [7]. The reasons and mechanisms that cause CINV are various. The activation of serotonin and dopamine receptors is believed to be the main cause for CINV. For these reasons, a 
FARMACIA, 2018, Vol. 66, 4

number of receptor antagonists have been developed. However, the control system of these drugs is only up to $90 \%$, and some patients still have CINV symptoms. Olanzapine is a multireceptors inhibitor, which was first used in clinical practice as an antipsychotic $[8,20]$. It has a high affinity for the serotonin (5-HT2A) and dopamine (D2) receptors, showing high antiemetic effects [9]. Some researchers have studied the related nursing effects of olanzapine on cancer patients after chemotherapy $[10,11]$, but there are still not enough studies that demonstrate the inhibitory effect of olanzapine on the incidence of CINV in patients with lung cancer after chemotherapy.

Kast et al [12] showed that olanzapine is an easyto-use psychoactive drug with potent antioxidant effects. It can prevent and reduce patients anxiety and improve sleep quality. Navari et al [13] showed that the combination of megestrol acetate and olanzapine can treat cancer-related anorexia. Suzuki et al [14] studied the effects of olanzapine in the treatment of nausea and vomiting caused by brain metastases. This study aimed to assess the utility of olanzapine in the lung cancer treatment, from preventing the CINV till its effect on invasion and metastasis of lung cancer. Three experiments are applied, one in vitro experiment on lung squamous cell carcinoma A549 cells to assess the olanzapine effect on cancer cell invasion, one in vivo study on nude mice non-obese diabetic (NOD)/severe combined immunodeficiency (SCID) lung metastasis model, for assessing the effect on lung metastasis and one clinical study for assessing the effect of preventing CINV.

\section{Materials and Methods}

In vitro study for assessing the effect of olanzapine on invasion and migration of lung squamous cell carcinoma

Cell culture: A549 cells from two groups were cultured at $37^{\circ} \mathrm{C}$ in a $5 \% \mathrm{CO}_{2}$ incubator (Thermo Fisher Scientific Company, USA).

Olanzapine cultured A549 cells were selected for the experimental group (concentration of olanzapine is $5 \mathrm{mg} / \mathrm{L}$ ), and A549 cells (without olanzapine cultured) were selected for the control group.

Migration experiment in vitro: for olanzapine cultured A549 cells, the number of cells in the logarithmic phase were counted, and $5 \times 103$ cells were counted every third day. The cells were cultured in a Transwell upper chamber and $500 \mathrm{~L}$ 10\% Foetal Bovine Serum (FBS) Roswell Park Memorial Institute (RPMI)-1640 complete medium (Gibco Company, USA) was used. Then the cells were placed into the 24 well-plate and cultured in the $5 \% \mathrm{CO}_{2}$ incubator at $37^{\circ} \mathrm{C}$ for 24 hours. The cells were removed and then placed in a 24 wellplate in advance with 4\% paraformaldehyde (Santa Cruz Company, China). Afterwards, it was dyed with $0.5 \%$ crystal violet (Sangon Biotech (Shanghai) Co., Ltd., China), washed with Phosphate Buffer Saline (PBS) (Shanghai Duma Biotechnology Co., Ltd., China), then placed on a clean tabletop to dry. The number of A549 cells migrated on the back of the membrane filter was counted under a microscope (Olympus Corporation, Japan).

Invasive experiment in vitro: RPMI-1640 incomplete medium (Gibco Company, USA) was diluted according to the $1: 10$ ratio, and $50 \mu \mathrm{L}$ medium was putted in a Transwell upper chamber. After 9 hours, the noncoagulated matrix glue on the upper margin of the Transwell was removed. $50 \mu \mathrm{L}$ RPMI-1640 incomplete culture medium was added after hydration. $2 \times 104$ A549 cells were counted and treated with olanzapine for 24 hours and inoculated in the upper chamber of the Transwell. The solution was cultured in a mixture of $95 \% \mathrm{O}_{2}$ and $5 \% \mathrm{CO}_{2}$ at $37^{\circ} \mathrm{C}$ for 48 hours, and the subsequent steps were the same as the migration experiments previously mentioned.

In vivo murine study for assessing the olanzapine effect on lung cancer metastasis

Twenty BALB/C male mice (5-8-week-old) were purchased from the Animal Experimental Center of Affiliated Hong Qi Hospital of $\mathrm{Mu}$ Dan Jiang Medical University, China. The animals were kept in standard conditions of $23 \pm 1{ }^{\circ} \mathrm{C}$ temperature, humidity between $40 \pm 5^{\circ} \mathrm{C}$ and 12 hours light/dark cycle. The mice were divided in two groups (10 mice in each group): the mice treated with olanzapine were selected as the experimental group (olanzapine $0.1 \mathrm{mg} / \mathrm{kg} \mathrm{bw} /$ day, i.p.); the mice treated with the normal saline solution were selected as the control group (received the same quantity of normal saline solution).

$1 \times 10^{6}$ A549 cells were counted and were suspended in $100 \mu \mathrm{L}$ PBS. $100 \mu \mathrm{L}$ A549 suspension was injected slowly into the nude mice by the tail vein. The weight of nude mice was recorded every three days, and the nude mice were sacrificed by cervical vertebra luxation at day 13. The number of A549 cells in the lung metastasis were observed and counted after the nude mice were dissected. This study was conducted in accordance with the International Directives for animal experiments and approved by the Ethical Committee of $\mathrm{Mu}$ Dan Jiang Medical University, China.

Clinical study for assessing the effect of olanzapine on preventing chemotherapy related nausea and vomiting in lung cancer patients

Thirty-eight lung cancer patients who received treatment with cisplatin combined pemetrexed in individualized doses according to the degree of 
FARMACIA, 2018, Vol. 66, 4

illness in the Affiliated Hong Qi Hospital of $\mathrm{Mu}$ Dan Jiang Medical University from March 2016 to March 2017 were included in the study. The experiment was approved by the Ethics Committee of Affiliated Hong Qi Hospital of Mu Dan Jiang Medical University, and all the subjects signed the informed consent for participating in the study. None of the enrolled patients had nausea and vomiting within 12 hours prior chemotherapy. The clinical data of the patients were collected from the medical records.

The patients were divided into two groups (19 patients in each group): olanzapine group that received: 5- hydroxytryptamine type 3 receptor antagonist granisetron (2 $\mathrm{mg} /$ day) (Wuhan Shengshi Huakang Biomedicine Technology Co., Ltd., Wuhan, China) with dexamethasone (4 mg/day) (Hangzhou Fu Luo Biological Technology Co., Ltd., Hangzhou, China), and olanzapine (5 mg/day) (Jiangsu Hausen Pharmaceutical Limited by Share Ltd., Lianyungang, China) and nonolanzapine group that received: Ganisetron (2 $\mathrm{mg}$ /day) with dexamethasone (4 mg/day).

The total number of nausea and vomiting incidences within five days, before and after olanzapine treatment, was observed and recorded for the two groups. The evaluation regarding the reaction of nausea, hiccup, dysemesia and vomiting after chemotherapy was made as follows: level 0 no nausea and vomiting; level I - vomiting; level II - temporary vomiting; level III - vomiting and need to be treated; level IV - vomiting difficult to control; $0+$ I mild nausea and vomiting, while II + III + IV moderate - severe nausea and vomiting.
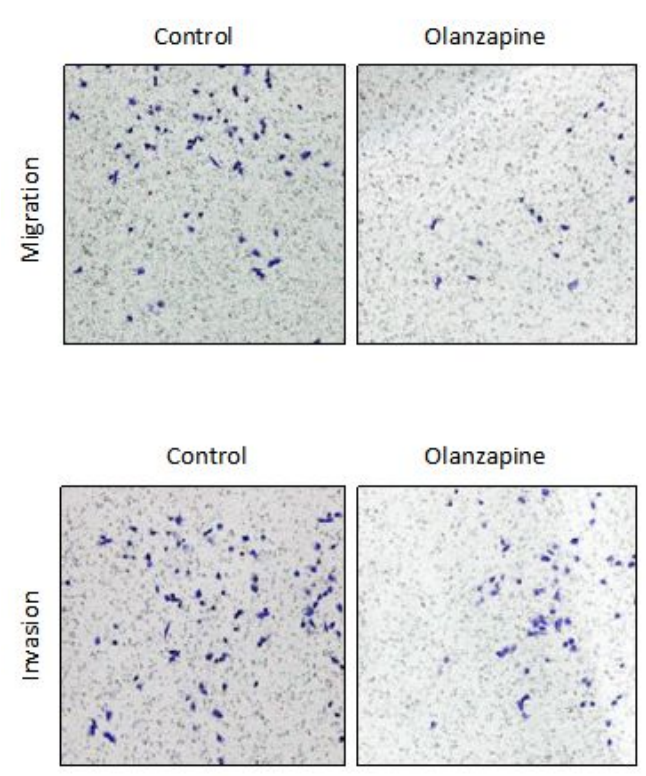

The changes of life quality related factors in the two groups were observed, including Eastern Cooperative Oncology Group (ECOG) score (0-5 points, higher score means worse health state and 5 means death of the patient), numerical rating scale (NRS) score (0 - 10 points, 0 : painless; 1 - 3: mild pain; 4 - 6: moderate pain; 7 - 10: severe pain) and sleep state $(0-4$ shows that there is no sleep disorder, 4 points or more indicates that the patient has some levels of sleep disorder) [15].

\section{Statistical analysis}

SPSS 16 software was used for the statistical analysis. The data were expressed as mean \pm standard deviation. Chi square test and Fisher's exact test was used to analyse the data in the clinical study and test was used to assess the differences between the groups for the in vivo animal experiment. The enumeration data were analysed by Chi square test. A p $<0.05$ was considered statistically significant.

\section{Results and Discussion}

In vitro study for assessing the effect of olanzapine on invasion and migration of lung squamous cell carcinoma

The results of the inhibition of olanzapine on the invasion and metastasis of A549 cells are shown in Figure 1, where the number of metastasis and invasion of A549 cells in control groups were significantly higher than that those of the experimental group. Compared to the control group, the number of A549 invading and penetrating the basement membrane decreased to $33.1 \pm 5.52 \%$ and $37.9+6.84 \%,(p<0.05)$.

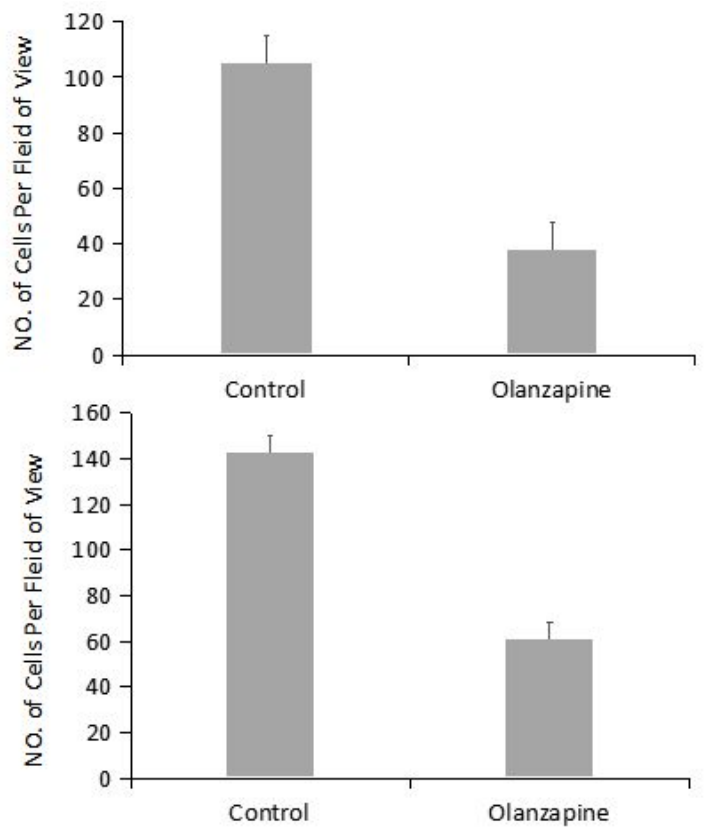

Figure 1.

Effects of olanzapine on migration and invasion of A549 cells 
FARMACIA, 2018, Vol. 66, 4

The results of the inhibition of olanzapine on the migration rate of A549 cells are shown in Figure 2. Compared with the control group, the migration rate in the experimental group decreased to $81.14 \pm$
$5.43 \%$ within 12 hours, and decreased to $58.97 \pm$ $9.21 \%$ within 36 hours. It decreased to $19.90 \pm$

$2.71 \%$ at 72 hours $(\mathrm{p}<0.05)$.

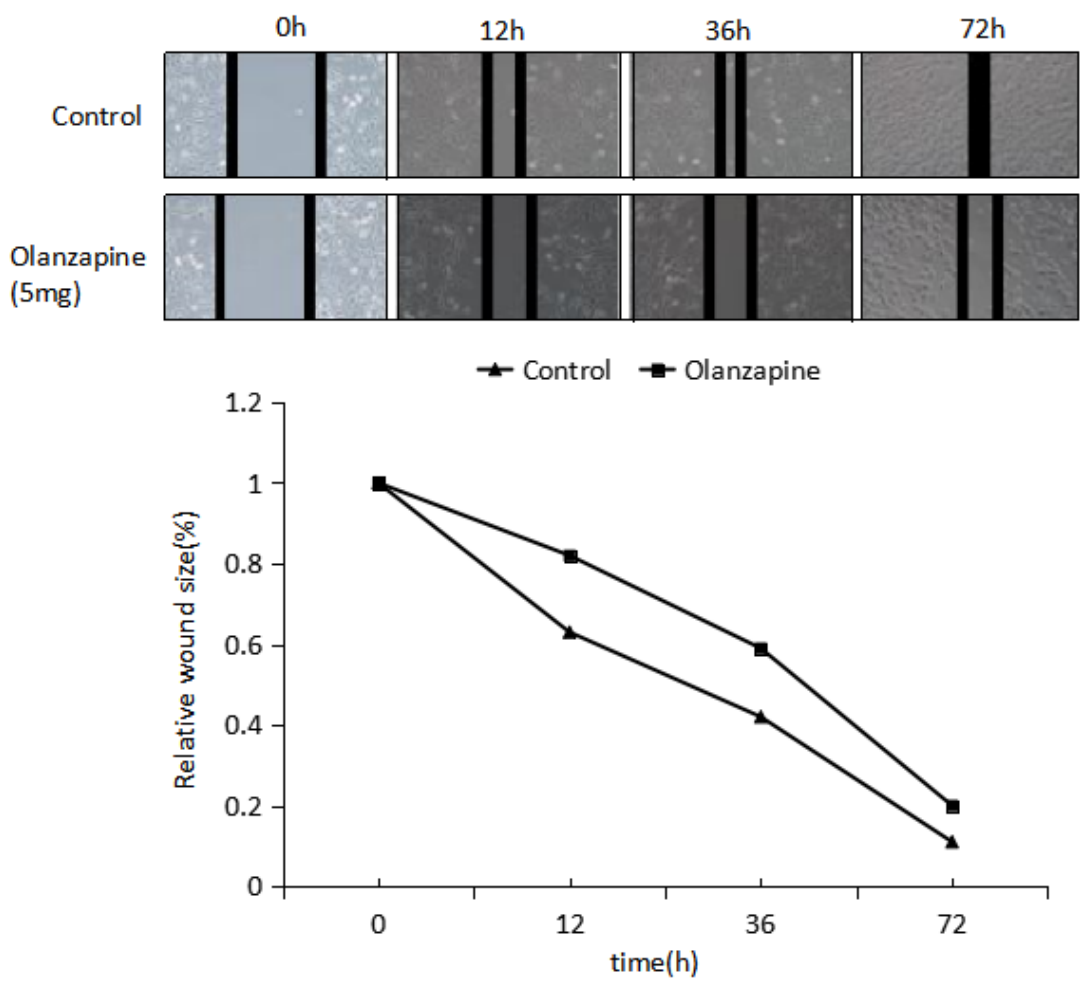

Figure 2.

Inhibitory effect of olanzapine on migration of A549

In vivo murine study for assessing the olanzapine effect on lung cancer metastasis

The effect of olanzapine on lung metastasis of A549 cells in nude mice is shown in Figure 3 and Table I. In the olanzapine group, measured by proportionally magnified images, the size $(\mu \mathrm{m})$ of A549 metastasis in lung tissue of nude mice was reduced to $56.5 \pm 11.9 \%$, and the difference was statistically significant $(\mathrm{p}<0.05)$.

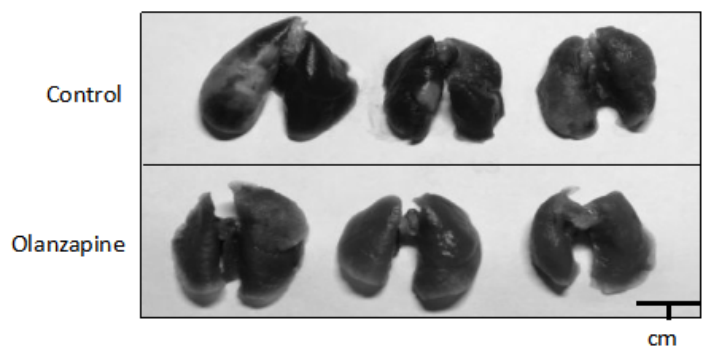

Figure 3.

Metastasis of lung tissue in nude mice in control group and experimental group
Table I

Size of A549 metastasis in lung tissue of nude mice in control group and experimental group ( $\overline{\mathrm{x}} \pm \mathrm{SD})$

\begin{tabular}{ccc}
\hline Group & Number & Size $(\mu \mathrm{m})$ \\
\hline Experimental group & 10 & $347.2 \pm 73.6$ \\
Control group & 10 & $547.9 \pm 91.3$ \\
\hline
\end{tabular}

Clinical study for assessing the effect of olanzapine on preventing chemotherapy related nausea and vomiting in lung cancer patients

At the beginning of the study there was no difference between the patients in the two groups (Table II). Compared with the non-combined olanzapine group, the number of patients in combined olanzapine groups were increased when the level was $0+$ I but decreased when the level was II + III + IV. As shown in Table III, the incidence of total CINV in the olanzapine group was significantly lower compared to the nonolanzapine group $(\mathrm{p}<0.05)$ (Table III). There were no differences between the two groups regarding the relative factors of life quality evaluated by ECOG score, NRS score and sleep (Table IV). 
Clinical characteristics of 38 patients

\begin{tabular}{|c|c|c|c|c|c|}
\hline \multirow{2}{*}{\multicolumn{2}{|c|}{ Clinical characteristics }} & \multirow{4}{*}{$\begin{array}{l}\text { Cases (\%) } \\
13(34.2) \\
25(65.8)\end{array}$} & \multicolumn{2}{|c|}{ Number of cases (\%) } & \multirow{4}{*}{$\begin{array}{c}\mathrm{p} \text { value } \\
0.361\end{array}$} \\
\hline & & & \multirow{3}{*}{$\begin{array}{c}\text { No nausea and } \\
\text { vomiting } \\
8(21.0) \\
19(50.0)\end{array}$} & \multirow{3}{*}{$\begin{array}{c}\begin{array}{c}\text { Nausea and } \\
\text { vomiting }\end{array} \\
5(13.2) \\
6(15.8)\end{array}$} & \\
\hline Gender & Male & & & & \\
\hline Gender & Female & & & & \\
\hline \multirow{2}{*}{ Age (years) } & $<60$ & $22(57.9)$ & $17(44.7)$ & $5(13.2)$ & \multirow{2}{*}{0.580} \\
\hline & $\geq 60$ & $16(42.1)$ & $10(26.3)$ & $6(15.8)$ & \\
\hline \multirow{2}{*}{ Smoking history } & Yes & $17(44.7)$ & $12(31.6)$ & $5(13.2)$ & \multirow{2}{*}{0.415} \\
\hline & No & $21(55.3)$ & $17(44.7)$ & $4(10.5)$ & \\
\hline \multirow{2}{*}{ Drinking history } & Yes & $19(50.0)$ & $15(39.5)$ & $4(10.5)$ & \multirow{2}{*}{0.569} \\
\hline & No & $19(50.0)$ & $16(42.1)$ & $3(7.9)$ & \\
\hline
\end{tabular}

Table III

Statistical analysis of olanzapine in the prevention of CINV

\begin{tabular}{cccc}
\hline \multirow{2}{*}{$\begin{array}{c}\text { Levels of nausea and } \\
\text { vomiting }\end{array}$} & \multicolumn{2}{c}{ Number of cases (\%) } & \multirow{2}{*}{ p value } \\
\cline { 2 - 3 } & Non olanzapine group & Olanzapine group & \\
\hline $0+$ I & $13(68.4)$ & $17(89.5)$ & \multirow{2}{*}{0.043} \\
II + III + IV & $6(31.6)$ & $2(10.5)$ & \\
\hline
\end{tabular}

Table IV

Comparative analysis of related factors of life quality in the two groups of patients

\begin{tabular}{ccccc}
\hline \multirow{2}{*}{ Clinical characteristics } & \multicolumn{2}{c}{ Number of cases (\%) } & \multirow{2}{*}{$\begin{array}{c}\text { pombined value } \\
\text { group }\end{array}$} \\
\cline { 2 - 3 } ECOG score & $\leq 1$ & $\begin{array}{c}\text { Non-combined } \\
\text { olanzapine group }\end{array}$ & $18(94.7)$ & \multirow{2}{*}{0.134} \\
NRS score & $>1$ & $3(84.2)$ & $1(5.3)$ & \\
& $=0$ & $15(78.9)$ & $17(89.5)$ & 0.173 \\
Sleep & $>0$ & $4(21.1)$ & $2(10.5)$ & \\
& $0-4$ & $12(63.2)$ & $16(84.2)$ & 0.051 \\
\hline
\end{tabular}

The incidence of CINV is as high as 70 to $80 \%$ in anti-tumor therapy, which is one of the main reasons threatening the patients to be unable to receive chemotherapy. In particular, highly emetic drugs or protocols have resulted in a 90 to $100 \%$ incidence of CINV for patients. The mechanism of CINV is complex and has not yet been completely elucidated. The main point of view is that it is related to 5-HT3, NK-1 and DA receptors, and even the factors such as sensation and mood can stimulate the cerebral cortex related pathways [16]. Although the preventive drugs such as NK-1RA (receptor antagonist), 5-HT3 RA and cortisol are used, there are still some patients that have not been fully controlled. Explosive CINV or refractory CINV still occurs, and salvage antiemetic therapy is required. Effective antiemetic drugs combined with different mechanisms, including antipsychotic drugs and benzodiazepines, may further improve the CINV control rate. It has been suggested that olanzapine is superior to conventional metoclopramide in the treatment of fulminant or refractory CINV [17]. Olanzapine can antagonize dopamine receptors, serotonin receptors (5-HT2A, 5-HT2C, 5-HT3, 5-HT6) and $\mathrm{M}$-type acetylcholine receptors, as a variety of nerve-humoral factor receptor inhibitors. Mizukami [18] believed that administrating olanzapine in the prevention and treatment of high-risk CINV can reduce the effect of chemotherapy on the life quality of patients. Navari [19] believed that olanzapine can increase patient's appetite and body weight. Chemo-therapy, interventional therapy, surgery, gene therapy and immunotherapy are the main treatment methods for treating cancer, and almost all cancer patients receive chemotherapy. Through comparative studies, it was found that olanzapine can inhibit CINV in patients with lung cancer and improve their life quality after chemotherapy. It can relieve the psychological pressure of cancer patients, improve the life quality and improve relieve the treatment's effect. However, there was no significant difference in ECOG score, NRS score and sleep quality between the two groups, which may be related to limited data in this study.

In order to further investigate the effect of olanzapine on tumour cells, we started from reported data in literature that showed that olanzapine inhibits proliferation and metastasis of tumour cells and promotes differentiation of tumour cells in tumour microenvironment [20]. In our study, olanzapine effectively inhibited the invasion and metastasis of A549 cells. These results suggest that olanzapine has a positive effect on the treatment of lung cancer. 
Furthermore, it was found that olanzapine can reduce the incidence of CINV, improve the sleep status of patients, and reduce the ECOG score and NRS score. This is important for the follow-up care of patients with chemotherapy. At the same time, olanzapine can inhibit the invasion and penetration of A549 cells, and also decreased the migration rate of A549. Meanwhile, it can reduce the number and size of distant metastasis of squamous cell carcinoma A549 transplantation tumour in nude mice, which is important for the treatment of lung squamous cell carcinoma.

\section{Conclusions}

Olanzapine can be used as adjuvant therapy for preventing chemotherapy-induced nausea and vomiting in lung cancer patients, having also the benefit of inhibiting the invasion and metastasis of lung cancer cells.

\section{Conflict of interest}

The authors declare no conflict of interests.

\section{References}

1. Song B, Wang LF, Fan XH, Zuo JH, Huang YM, Expression of T-lymphoma invasion and metastasis factor on the occurrence of oral squamous cell carcinoma. J Biol Regul Homeost Agents, 2017; 31(2): 289-296.

2. Hao E, Yu J, Xie S, Zhang W, Wang G, Upregulation of miR-888-5p in hepatocellular carcinoma cell lines and its effect on malignant characteristics of cells. J Biol Regul Homeost Agents, 2017; 31(1): 163-170.

3. Molassiotis A, Brearley SG, Stamataki Z. Use of antiemetics in the management of chemotherapyrelated nausea and vomiting in current UK practice. Support Care Cancer, 2011; 19: 949-956.

4. Maturu P, Wei-Liang Y, Androutsopoulos VP, Jiang W, Wang L, Tsatsakis AM, Quercetin attenuates the hyperoxic lung injury in neonatal mice: Implications for Bronchopulmonary dysplasia (BPD). Food Chem Toxicol., 2018; 114: 23-33.

5. Gavrilovici C, Luca A, Antoniu SA, Gallaby K, Ştefănescu R, Stârcea M, Miron I, Bild V, How nephrotoxic is the cancer therapy in children? Farmacia, 2017; 66(2): 197-208.

6. Hamza RZ, El-Shenawy NS, Anti-inflammatory and antioxidant role of resveratrol on nicotineinduced lung changes in male rats. Toxicology Reports, 2017; 4: 399-407.

7. Poonacha TK, Go RS, Level of scientific evidence underlying recommendations arising from the National Comprehensive Cancer Network clinical practice guidelines. J Clin Oncol, 2011; 29: 186-191.

8. Hesketh PJ, Wright O, Rosati G, Russo M, Levin J, Lane S, Moiseyenko V, Single-dose intravenous casopitant in combination with ondansetron and dexamethasone for the prevention of oxaliplatin- induced nausea and vomiting: a multicenter, randomized, double-blind, active-controlled, two arm, parallel group study. Support Care Cancer, 2012; 20(7): 1471-1478.

9. Rojas C, Raje M, Tsukamoto T, Slusher BS, Molecular mechanisms of 5-HT(3) and NK(1) receptor antagonists in prevention of emesis. Eur $J$ Pharmacol., 2014; 722: 26-37.

10. Tan L, Liu J, Liu X, Chen J, Yan Z, Yang H, Zhang $\mathrm{D}$, Clinical research of Olanzapine for prevention of chemotherapy-induced nausea and vomiting. $J$ Exp Clin Cancer Res., 2009; 28: 1-7.

11. Kaneishi K, Kawabata M, Morita T, Olanzapine for the relief of nausea in patients with advanced cancer and incomplete bowel obstruction. J Pain Symptom Manage., 2012; 44(4): 604-607

12. Kast RE, Foley KF, Cancer chemotherapy and cachexia: mirtazapine and olanzapine are 5-HT3 antagonists with good antinausea effects. Eur $J$ Cancer Care., 2007; 16(4): 351-354.

13. Navari RM, Brenner MC, Treatment of cancerrelated anorexia with olanzapine and megestrol acetate: a randomized trial. Support Care in Cancer., 2010; 18(8): 951-956.

14. Suzuki M, Komuro K, Ohara K. Olanzapine and Betamethasone Are Effective for the Treatment of Nausea and Vomiting due to Metastatic Brain Tumors of Rectal Cancer. Case Rep Gastroenterol. 2014, 8(1):13-17.

15. Pu R, Zhao Q, Li Z, Zhang L, Luo X, Zeren Y, Yu $\mathrm{C}, \mathrm{Li} \mathrm{X}$, Rapid bone repair in a patient with lung cancer metastases to the spine using a novel herbal medicine: A case report. Oncol Lett., 2016; 12(3): 2023-2027.

16. Grassi L, Berardi MA, Ruffilli F, Meggiolaro E, Andritsch E, Sirgo A, Caruso R, Juan Linares E, Role of psychosocial variables on chemotherapyinduced nausea and vomiting and health-related quality of life among cancer patients: a European study. Psychother Psychosom., 2015; 84(6): 339-347.

17. Mizukami N, Yamauchi M, Koike K, Watanabe A, Ichihara K, Masumori N, Yamakage M, Olanzapine for the prevention of chemotherapy-induced nausea and vomiting in patients receiving highly or moderately emetogenic chemotherapy: a randomized, double-blind, placebo-controlled study. $J$ Pain Symptom Manage., 2014; 47(3):542-550.

18. Ösz BE, Tero-Vescan A, Dogaru M, Vancea S, Imre S, Bosa P, Vari CE, Olanzapine transfer into sheep's milk. An animal model. Farmacia, 2017; 65(5): 677-682.

19. Navari RM, Gray SE, Kerr AC, Olanzapine versus aprepitant for the prevention of chemotherapyinduced nausea and vomiting: a randomized phase III trial. J Support Oncol., 2011; 9(5): 188-195.

20. Torigoe K, Nakahara K, Rahmadi M, Yoshizawa K, Horiuchi H, Hirayama S, Imai S, Kuzumaki N, Itoh T, Yamashita A, Shakunaga K, Yamasaki M, Nagase H, Matoba M, Suzuki T, Narita M, Usefulness of olanzapine as an adjunct to opioid treatment and for the treatment of neuropathic pain. Anesthesiology, 2012; 116(1): 159-169. 